\title{
Production of Gentamycin and Ceftiofur Specific Polyclonal Antibodies by Conjugating them with Bovine Serum Albumin
}

\section{Sampath Kumar $\mathbf{B}^{1^{*}}$, Vasili Ashok ${ }^{1}$, Kalyani $\mathbf{P}^{1}$, Eswar Prasad $\mathbf{P}^{1}$ and Krishnaiah $\mathbf{N}^{1}$}

${ }^{1}$ Veterinary Biochemistry, Shri PV Narasimha Rao Telangana State University for Veterinary, Animal and Fishery Sciences, New Indira Nagar, Seetha Ram Bagh, Hyderabad, Telangana, India

${ }^{2}$ College of Veterinary Science, Korutla, Karimnagar, Telangana, India

"Corresponding author: Sampath Kumar B, Veterinary Biochemistry, Shri PV Narasimha Rao Telangana State University for Veterinary, Animal and Fishery Sciences, New Indira Nagar, Seetha Ram Bagh, Hyderabad, Telangana, India, Tel: 09989673085; E-mail: samkum85@gmail.com

Rec date: Feb 02, 2016; Acc date: Mar 29, 2016; Pub date: Mar 31, 2016

Copyright: $\odot 2016$ Kumar SB, et al. This is an open-access article distributed under the terms of the Creative Commons Attribution License, which permits unrestricted use, distribution, and reproduction in any medium, provided the original author and source are credited.

\begin{abstract}
Polyclonal antibodies (pAbs) were produced against gentamycin (GEN) and ceftiofur (CEF) antibiotics in sprague dawley rats (aged 7-8 weeks) by conjugating them with bovine serum albumin (BSA). Total 3 groups (3 rats in each group): one control (without antibiotic) group and two test groups (GEN and CEF) of rats were maintained. Total of four blood samplings were done from each group as follows: First three samples was serially at 15 days' time interval after $1^{\text {st }}$ booster, $2^{\text {nd }}$ booster, $3^{\text {rd }}$ booster and the $4^{\text {th }}$ sampling was one and half month after the third booster. The antibody titres in the antisera of each antibiotic in all the four immunization cycles were determined by an icELISA at various serum dilutions ranging from $1 / 100$ to $1 / 6400$. Analysis of antibiotic conjugates by SDS-PAGE and Coomassie blue staining revealed higher molecular weights when compared to normal BSA (68 KDa). The molecular weights of conjugates were $90 \mathrm{kDa}, 78 \mathrm{kDa}$ for GEN-BSA and CEF-BSA respectively. The GEN antisera gave positive antibody titres up to a dilution of $1 / 1600$ in first immunization cycle, $1 / 6400$ in $2^{\text {nd }}$ and $3^{\text {rd }}$ immunization cycles and $1 / 1600$ in $4^{\text {th }}$ sampling. Maximum optical density at $450 \mathrm{~nm}\left(\mathrm{OD}_{450}\right)$ value of 0.928 was obtained at $1 / 100$ antiserum dilution in 3rd immunization cycle. The CEF antisera gave positive antibody titres up to a dilution of $1 / 800$ in 1 st immunization cycle, $1 / 1600$ in $2^{\text {nd }}$ immunization cycle, $1 / 6400$ in $3^{\text {rd }}$ immunization cycle and $1 / 3200$ in $4^{\text {th }}$ sampling. Maximum $\mathrm{OD}_{450}$ value of 2.072 was obtained at $1 / 100$ antiserum dilution in $3^{\text {rd }}$ immunization cycle.
\end{abstract}

Keywords: Conjugation of antibiotics; 1-Ethyl-3-(3dimethylaminopropyl) Carbodiimide; Indirect competitive ELISA, Bovine serum albumin

\section{Introduction}

The use of antibiotics as prophylactic agents, growth promoters, therapeutic agents, in the treatment of pyrexia, inflammation, wounds and viral diseases in lactating cattle and buffaloes is responsible for their presence in the milk [1]. Animals are exploited for more production and profit with extensive use of antibiotics as growth promoters contributing significantly to drug residues being present in milk [2]. Sub-therapeutic use of antibiotics as growth promoters or to control endemic infections cause development of drug resistance [3]. There is a considerable evidence for the development of antibiotic resistance in bacterial species that cause zoonotic infections like Salmonella enterica serotypes, Campylobacter jejuni, Escherichia coli and Enterococci due to the use of antibiotics as growth promoters [4].

Antibiotics residues in milk higher than MRL (Maximum residue levels) are of great concern to dairy farmers, milk processors, regulatory agencies, and consumers due to their possible adverse effects on people allergic to antibiotics and potential build-up of antibiotic-resistant organisms in humans [5]. All these results emphasize the need to have strict control measures on the use of antibiotics in veterinary practice both as therapeutic as well as prophylactic agents and also the need to have rapid and sensitive screening methods to detect antibiotic residues in milk samples.
To develop an antibiotic specific immunologic assay, pAbs against specific antibiotic structure is required [6]. To incite an immune response, the molecular weight of the antigen should be minimum of $10 \mathrm{kDa}$ [7]. Low molecular weight and incomplete antigens (haptens) like antibiotics are conjugated with carrier protein like BSA [8].

This study was undertaken to produce pAbs against GEN and CEF antibiotics and detection of these pAbs by a sensitive icELISA in antibiotic specific antisera. The pAbs produced can be employed for detecting GEN and CEF residues in milk samples.

\section{Materials and Methods}

\section{Animals}

Sprague Dawley rats aged 7-8 weeks were kept under well lighted experimental house and maintained on standard rat feed with ad libitum water. A total of 3 groups were maintained, two test groups (for GEN and CEF) and one control group (without antibiotic) each with 3 rats in a group.

\section{Ethical approval}

The experimental protocol was approved by the university animal ethics committee under order no 8/i/10.

\section{Conjugation of GEN}

$3.5 \mathrm{ml}$ of GEN $(40 \mathrm{mg} / \mathrm{ml})$ and $20 \mathrm{mg}$ of BSA were taken into a clean beaker. $580 \mathrm{mg}$ of EDC was dissolved in $2 \mathrm{ml}$ of distilled water 
and was added drop wise to the above mixture, accompanied by continuous stirring on a magnetic stirrer. The $\mathrm{pH}$ of the solution was adjusted to $5.0-6.0$ by adding $0.1 \mathrm{~N} \mathrm{HCl}$ as method described by Haasnoot et al. with slight modifications [9].

\section{Conjugation of CEF}

$2.5 \mathrm{ml}$ of CEF $(100 \mathrm{mg} / \mathrm{ml})$ and $20 \mathrm{mg}$ of BSA were taken into a clean beaker. $580 \mathrm{mg}$ of EDC was dissolved in $2 \mathrm{ml}$ of distilled water and was added drop wise to the above mixture, accompanied by continuous stirring on a magnetic stirrer. The $\mathrm{pH}$ of the solution was adjusted to $5.0-6.0$ by adding $0.1 \mathrm{~N} \mathrm{HCl}$ as described by Stanker et al. with slight modifications [10].

The above reaction mixtures of GEN-EDC and CEF-EDC were incubated at room temperature (RT) in separate beakers with continuous stirring for 2 hours. After the reaction time of 2 hours, uncoupled antibiotic and EDC were removed by dialysis.

Determination of successful conjugation

The conjugated samples were analyzed by SDS PAGE to confirm successful conjugation [11]. SDS PAGE was performed according to the method described by Bollag et al. [12]. The images of the stained gels were taken in the gel documentation system (G-box-Syngene).

\section{Immunogen preparation for primary immunization}

For preparation of GEN immunogen $35 \mu \mathrm{l}$ of GEN-BSA conjugate was added to $465 \mu \mathrm{l}$ phosphate buffer saline (PBS) buffer and $500 \mu \mathrm{l}$ of complete freund's adjuvant (FCA) and for CEF immunogen preparation $40 \mu \mathrm{l}$ of CEF-BSA conjugate was added to $460 \mu \mathrm{l}$ PBS buffer and $500 \mu \mathrm{l}$ of FCA as described by Dykman et al. [13].

\section{Immunogen preparation for booster immunization}

For preparation of GEN booster immunogen $35 \mu \mathrm{l}$ of GEN-BSA conjugate was added to $465 \mu \mathrm{l}$ PBS buffer and $500 \mu$ lof incomplete freund's adjuvant (FIA) and for CEF immunogen preparation $40 \mu \mathrm{l}$ of CEF-BSA conjugate was added to $460 \mu \mathrm{l}$ PBS buffer and $500 \mu \mathrm{l}$ of FIA [13].

The immunogen was mixed thoroughly and $300 \mu \mathrm{l}(150 \mu \mathrm{l}$ for each site) was injected to each rat (test group) subcutaneously at two different sites according to the immunization schedule as described by Dykman et al. [13].

\section{Collection of blood from rats}

The blood was collected by orbital sinus veni puncture method described by Oruganti and Gaidhani [14]. Total of four blood collections were made in each group at different time intervals according to the schedule given by Dykman et al. with slight modifications (Table 1) [13].

\section{Estimation of Total protein, albumin and $A / G$ ratio}

The serum samples of each test group (GEN and CEF) and control group animals collected after second booster (third immunization cycle) were analyzed for total protein, albumin and A/G ratio by using Ensure Biotech Total Protein andAlbumin teaching kit.

\section{Preparation of ELISA antigens (casein-antibiotic conjugates)}

Casein $(0.83 \mu \mathrm{mol})$ was dissolved in $2 \mathrm{ml}$ of distilled water in the presence of small amount of sodium-bi-carbonate to maintain alkaline condition. $83 \mu \mathrm{mol}$ of antibiotic and $83 \mu \mathrm{mol}$ of EDC were added to the above protein solution. Reaction mixture was stirred on a magnetic stirrer continuously for $2 \mathrm{hrs}$ at room temperature. The $\mathrm{pH}$ of the solution was adjusted to 5.0. Reaction mixtures of all the two antibiotics were then incubated overnight at $4^{\circ} \mathrm{C}$. Conjugates were dialyzed against distilled water as the method given by Samsonova et al. [15].

\begin{tabular}{|l|l|}
\hline Immunization Schedule & Procedure \\
\hline Day 0 & 1st Immunization antigen+CFA \\
\hline Day 15 & 1st Boost antigen+ICFA \\
\hline Day 30 & 1st Test Bleed \\
\hline Day 37 & 2nd Boost antigen+ICFA \\
\hline Day 52 & 2nd Test Bleed \\
\hline Day 59 & 3rd Boost antigen+ICFA \\
\hline Day 74 & 3rd Test Bleed \\
\hline Day 104 & 4th Test Bleed \\
\hline CFA: Complete freund's adjuvant ICFA: Incomplete freund's adjuvant, \\
\hline
\end{tabular}

Table 1: Immunization schedule.

\section{Indirect ELISA}

96 well flat bottom polystyrene ELISA plates (Nunc, Denmark) were coated with $250 \mu \mathrm{l}$ of antigen (antibiotic-casein conjugate) in $0.01 \mathrm{M}$ carbonate buffer ( $\mathrm{pH}-9.6)$. The plate was incubated overnight at $4^{\circ} \mathrm{C}$. The wells were washed 3 times with PBS that contained $0.05 \%$ Tween 20 (PBST), $250 \mu \mathrm{l} /$ well. The free (unbound) sites were blocked with $2 \%$ casein in blocking buffer, $250 \mu \mathrm{l} /$ well. The plate was incubated at $37^{\circ} \mathrm{C}$ for 1 hour. The wells were washed three times with PBS, $250 \mu \mathrm{l} /$ well. $100 \mu \mathrm{l}$ of diluted antiserum samples $(1 / 100,1 / 200,1 / 400,1 / 800$, $1 / 1600,1 / 3200,1 / 6400)$ in PBST were added to each well and the plate was incubated for $1 \mathrm{hr}$ at $37^{\circ} \mathrm{C}$. The wells were washed 3 times with PBST $(250 \mu \mathrm{l} /$ well per wash cycle). $100 \mu \mathrm{l}$ of conjugate of secondary antibodies with horseradish peroxidase in PBST was added to each well and the plate was incubated for $1 \mathrm{hr}$ at $37^{\circ} \mathrm{C}$. The wells were washed 3 times with PBST $(250 \mu \mathrm{l} /$ well per wash cycle). $100 \mu \mathrm{l}$ of the substrate $(3,3,5,5$ ' tetramethylbenzidine) in PBST ( 1 in 20 dilution) was added to each well. Reaction was stopped after 10-15 minutes by adding $50 \mu \mathrm{l} /$ well of $4 \mathrm{M} \mathrm{H}_{2} \mathrm{SO}_{4}$ as the method described by Samsonova et al. [15]. Optical density was measured by using ELISA microtitre plate reader at $450 \mathrm{~nm}$ (Biotech instrument- $\mu$ quant).

\section{Standardization of indirect competitive ELISA}

The serum samples collected after second booster $\left(3^{\text {rd }}\right.$ immunization cycle) were used for the standardization. Checker board titration was performed using different dilutions of antigens against different serum dilutions of test groups and negative control at constant secondary antibody-HRP conjugate dilution of $1 / 10000$ (manufacturer's instruction). Serial antigen dilutions (from $2 \times 10^{6}$ $\mathrm{ng} / \mathrm{ml}$ to $2 \mathrm{ng} / \mathrm{ml}$ ) were taken from rows $\mathrm{B}$ to $\mathrm{H}$ in 96 well polystyrene 
plates and serial primary antibody dilutions (from $1 / 50$ to $1 / 1600$ ) were taken from columns 1 to 6 for test group samples and columns 7 to 12 for control group samples. The dilution of antigen which showed, maximum absorbance reading and started to maintain almost a stationary phase was taken as the optimum according to the procedure described by Fan et al. [16].

\section{Testing the antiserum samples for antibody titres}

The antibody titres in the serum samples collected from immunized rats were tested by icELISA standardized as described above. The optimum antigen concentrations and primary antibody dilutions obtained for the antibiotics by the above described method were used for the test. The antisera of all the three animals in each group collected during all the three immunization cycles and $4^{\text {th }}$ sampling were tested at various serum dilutions ranging from $1 / 100$ to $1 / 1600$. Each sample was tested in duplicate including the control serum samples. In the reagent blank, PBST was added instead of antiserum. In the negative control wells, serum samples of control group rats were added. The mean $\mathrm{OD}_{450}$ of various serum dilutions at each immunization cycle for each group of rats were used to plot a graph with absorbance on $y$-axis and serum dilutions on $\mathrm{X}$-axis.

\section{Construction of PNT base line}

The mean and the standard deviation values of the control group at each dilution ranging from $1 / 100$ to $1 / 6400$ were calculated for each of the two different antigen coated plates used in the present study. Three units of standard deviation were added to the corresponding mean absorbance value and a graph was plotted with values of mean plus three times standard deviation $(\mathrm{M}+3 \mathrm{SD})$ on $\mathrm{y}$-axis and serum dilutions on $\mathrm{x}$-axis. This was considered as positive negative threshold (PNT) baseline [17]. Separate PNT baselines were constructed for each test group.

\section{Prediction of antibody titres}

The positive antibody titres were determined based on the cut off value obtained from PNT base line constructed. The highest $\mathrm{OD}_{450}$ value of the PNT baseline rounded off to the nearest single digit decimal was taken as cut off value. The $\mathrm{OD}_{450}$ value over and above the cut off value was considered as positive antibody titre [17].

\section{Results and Discussion}

\section{Determination of successful conjugation}

GEN and CEF antibiotics were conjugated with BSA by using EDC as a crosslinker by employing carbodiimide method. Analysis of antibiotic conjugates by SDS-PAGE and Coomassie blue staining revealed higher molecular weights of antibiotic-BSA conjugates when compared to normal BSA (Figure 1). Before conjugation with antibiotic, the molecular weight of BSA was $68 \mathrm{KDa}$. After conjugation, the molecular weights of conjugates were $90 \mathrm{kDa}, 78 \mathrm{kDa}$ for GENBSA and CEF-BSA respectively. These results clearly indicate the successful conjugation of antibiotics with BSA. These results are similar with Jiang et al. [18] Where sarafloxacin-BSA conjugate was analysed on SDS PAGE by observing the increased molecular weights of a conjugate.

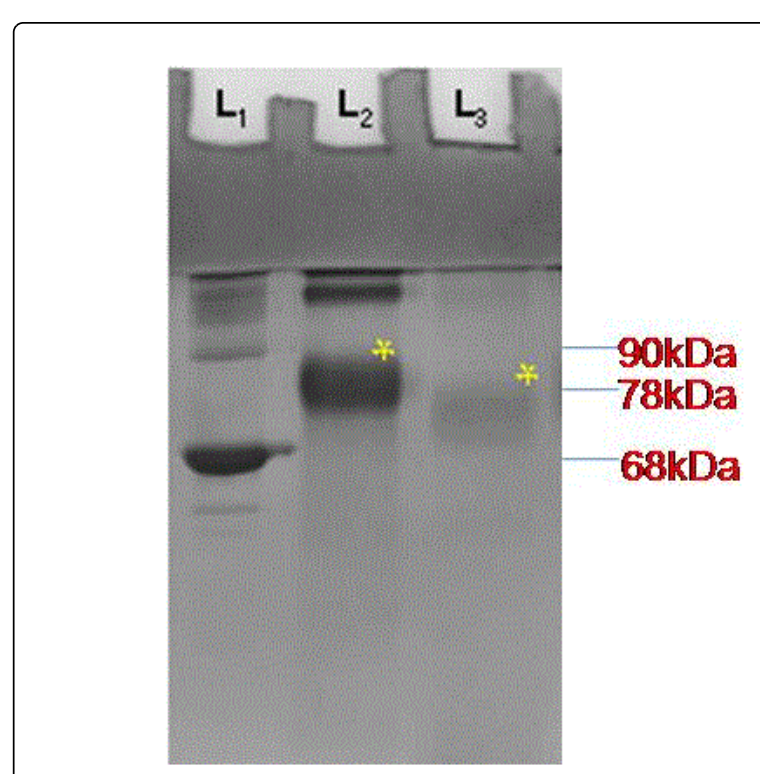

Figure 1: Coomassie blue stained SDS PAGE gel of antibiotic conjugates. $\mathrm{L}_{1}$-Bovine serum albumin, $\mathrm{L}_{2}$-Gentamycin conjugate, $\mathrm{L}_{3}$-Ceftiofur conjugate, $\left(^{*}\right)$ conjugates.

\section{Estimation of total protein, albumin and $A / G$ ratio}

The mean values of total protein, albumin, and globulin and A/G ratio of serum samples collected during third immunization cycle. The mean total protein concentration was $8.25 \pm 0.20 \mathrm{~g} / \mathrm{dL}, 30 \pm 1.20 \mathrm{~g} / \mathrm{dL}$ for GEN and CEF antisera respectively and in the control group it was $6.66 \pm 0.01 \mathrm{~g} / \mathrm{dL}$. The mean albumin concentration was $2.93 \pm 0.14$ $\mathrm{g} / \mathrm{dL}, 3.44 \pm 0.020 \mathrm{~g} / \mathrm{dL}$ for GEN and CEF antisera respectively compared $3.36 \pm 0.173 \mathrm{~g} / \mathrm{dL}$ in the control group. The mean globulin concentration was $5.23 \pm 0.05 \mathrm{~g} / \mathrm{dL}, 26.56 \pm 1.18 \mathrm{~g} / \mathrm{dL}$ for GEN and $\mathrm{CEF}$ antisera respectively, where it was $3.30 \pm 0.04 \mathrm{~g} / \mathrm{dL}$ in the control group. The mean A/G ratio was $0.55 \pm 0.023,0.13 \pm 0.020$ for GEN and $\mathrm{CEF}$ respectively. The mean $\mathrm{A} / \mathrm{G}$ ratio in the control group serum was $1.02 \pm 0.012$. Thrall [19] reported that $A / G$ ratio was altered due to increase in total protein concentration and particularly globulin concentration in the serum. Increased globulin concentration and decreased $A / G$ ratio indicates the presence of antibodies in the antisera.

\section{Standardization of antigen concentration and antiserum dilution for Indirect ELISA}

In all the checker board titrations the $\mathrm{OD}_{450}$ values of the test wells increased suddenly from the coated antigen concentration of $2 \mathrm{ng} / \mathrm{ml}$ to $20 \mathrm{ng} / \mathrm{ml}$ and continued to maintain a steady phase at higher concentrations. So, $20 \mathrm{ng} / \mathrm{ml}$ was chosen as optimum antigen concentration. The absorbance values of the negative control wells dropped suddenly from serum dilution of $1 / 50$ to $1 / 100$ and continued to maintain similar range at higher dilutions and at all antigen concentrations. The test wells continued to maintain higher absorbance values at corresponding dilutions. Hence $1 / 100$ was chosen as optimum serum dilution. The highest mean plus three times standard deviation values $(\mathrm{M}+3 \mathrm{SD})$ values obtained for negative sera were 0.207 (Table 2) and 0.211 (Table 3) for GEN-casein and CEF- 
Citation: Kumar SB, Ashok V, Kalyani P, Prasad PE, Krishnaiah N (2016) Production of Gentamycin and Ceftiofur Specific Polyclonal Antibodies by Conjugating them with Bovine Serum Albumin. J Veterinar Sci Techno 7: 314. doi:10.4172/2157-7579.1000314

Page 4 of 6

casein coated plates respectively. Hence the cut off value was selected as 0.3 for antibiotics.

\begin{tabular}{|c|c|c|c|c|c|c|c|}
\hline \multirow[t]{2}{*}{ Immunization cycles } & \multicolumn{7}{|c|}{ Serum dilutions } \\
\hline & $1 / 100$ & $1 / 200$ & $1 / 400$ & $1 / 800$ & $1 / 1600$ & $1 / 3200$ & $1 / 6400$ \\
\hline $1 \mathrm{st} I \mathrm{C}$ & 0.739 & 0.620 & 0.484 & 0.386 & 0.315 & 0.285 & 0.255 \\
\hline 2nd IC & 0.824 & 0.725 & 0.586 & 0.465 & 0.373 & 0.334 & 0.314 \\
\hline 3rd IC & 0.928 & 0.815 & 0.679 & 0.535 & 0.436 & 0.365 & 0.342 \\
\hline 4th Sampling & 0.792 & 0.677 & 0.527 & 0.408 & 0.307 & 0.281 & 0.212 \\
\hline $\begin{array}{l}\text { Negative control }(M+3 S D) \\
(M+3 S D)\end{array}$ & 0.207 & 0.203 & 0.191 & 0.109 & 0.111 & 0.097 & 0.091 \\
\hline
\end{tabular}

Table 2: Mean $\mathrm{OD}_{450}$ values of indirect ELISA of gentamycin antisera (Bold numbers indicate $50 \%$ titres).

\begin{tabular}{|l|l|l|l|l|l|l|l|}
\hline \multirow{2}{*}{ Immunization cycles } & \multicolumn{4}{l}{ Serum dilutions } \\
\cline { 2 - 9 } & $\mathbf{1 / 1 0 0}$ & $\mathbf{1 / 2 0 0}$ & $\mathbf{1 / 4 0 0}$ & $\mathbf{1 / 8 0 0}$ & $\mathbf{1 / 1 6 0 0}$ & $\mathbf{1 / 3 2 0 0}$ & $\mathbf{1 / 6 4 0 0}$ \\
\hline 1st IC & 0.905 & 0.784 & 0.59 & 0.428 & 0.283 & 0.094 & 0.068 \\
\hline 2nd IC & 1.052 & 0.97 & 0.807 & 0.528 & 0.358 & 0.198 & 0.135 \\
\hline 3rd IC & 2.072 & 1.865 & 1.581 & 1.324 & 1.239 & 1.11 & 1.041 \\
\hline 4th IC & 1.458 & 1.282 & 0.999 & 0.84 & 0.633 & 0.435 & 0.25 \\
\hline $\begin{array}{l}\text { Negative control } \\
\text { (M+3SD) }\end{array}$ & 0.211 & 0.207 & 0.218 & 0.175 & 0.115 & 0.121 & 0.110 \\
\hline
\end{tabular}

Table 3: Mean $\mathrm{OD}_{450}$ values of indirect ELISA of ceftiofur antisera (Bold numbers indicate $50 \%$ titres).

\section{Detection of antibody titres in the GEN antisera}

The highest $\mathrm{M}+3 \mathrm{SD}$ value of negative control was 0.207 (Table 2). The cut off value was selected as 0.3 (nearest single digit decimal above 0.207). The mean $\mathrm{OD}_{450}$ values of the gentamycin antisera were above the cut-off value up to serum dilution of $1 / 600$ in all the immunization cycles which indicated positive antibody titres (Table 2, Figure 2). The values of $50 \%$ antibody titres increased from the antiserum dilution of $1 / 800$ in $1^{\text {st }}$ immunization cycle to $1 / 6400$ in $3^{\text {rd }}$ immunization cycle (Table 2). The gentamycin antisera gave positive antibody titres up to a dilution of $1 / 1600$ in first immunization cycle, $1 / 6400$ in $2^{\text {nd }}$ and $3^{\text {rd }}$ immunization cycles and $1 / 1600$ in $4^{\text {th }}$ sampling. Highest antibody titre was obtained after primary immunization by plate trapped antigen ELISA [20] and after second boosting by indirect ELISA [21] in gentamycin antisera. Gentamycin antisera after $11^{\text {th }}$ booster and streptomycin antisera after $6^{\text {th }}$ booster were used to confirm specific immune response in rabbits by ELISA [9]. Maximum $\mathrm{OD}_{450}$ value of 0.928 was obtained at $1 / 100$ antiserum dilution in $3^{\text {rd }}$ immunization cycle (Figure 2) which clearly indicated that the immune response was the highest in $3^{\text {rd }}$ immunization cycle (Table 2). The immune response significantly increased from $1^{\text {st }}$ immunization cycle to $3^{\text {rd }}$ immunization cycle at 1/100 antiserum dilution and decreased in 4th collection (Figure 2).

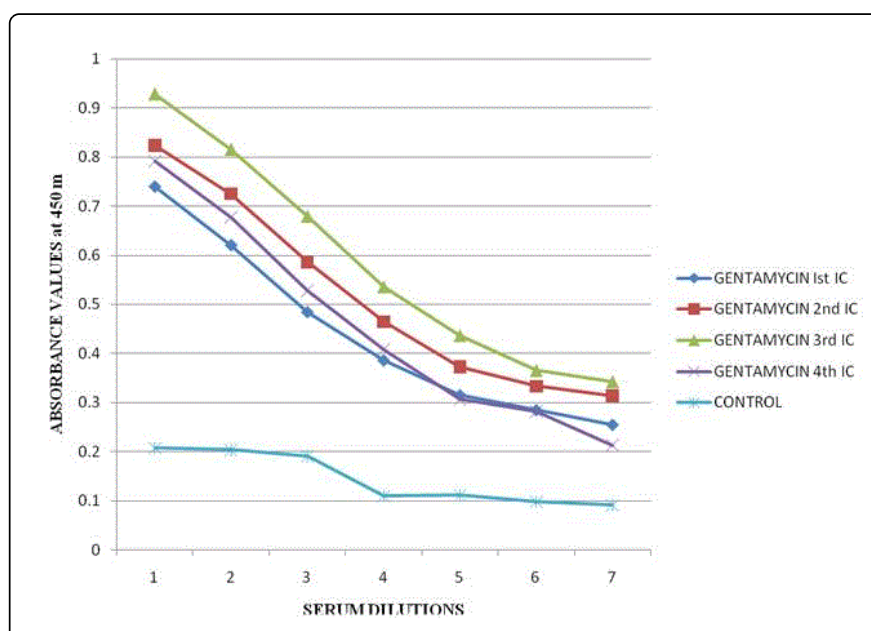

Figure 2: Calibration curve for Indirect ELISA of BSA-Gentamycin antisera at various immunization cycles (IC) $(1,2,3,4,5,6,7$ represents serum dilutions of $1 / 100,1 / 200,1 / 400,1 / 800,1 / 1600$, $1 / 3200$ and $1 / 6400$ respectively). 


\section{Detection of antibody titres in the CEF antisera}

The highest $\mathrm{M}+3 \mathrm{SD}$ values of negative control was 0.211 (Table 3). The cut-off value was selected as 0.3 (nearest single digit decimal above 0.211). The mean $\mathrm{OD}_{450}$ values of the serum samples from immunized rats were above the cut-off value up to serum dilution of $1 / 800$ in all the three immunization cycles and fourth sampling which indicated positive antibody titres (Table 3 , Figure 3 ). The values of $50 \%$ antibody titres increased from the antiserum dilution of $1 / 800$ in $1^{\text {st }}$ immunization cycle to $1 / 6400$ in $3^{\text {rd }}$ immunization cycle (Table 3 ). The ceftiofur antisera gave positive antibody titres up to a dilution of $1 / 800$ in $1^{\text {st }}$ immunization cycle, $1 / 1600$ in $2^{\text {nd }}$ immunization cycle, $1 / 6400$ in $3^{\text {rd }}$ immunization cycle and $1 / 3200$ in $4^{\text {th }}$ sampling (Figure 3 ). Maximum $\mathrm{OD}_{450}$ value of 2.072 was obtained at $1 / 100$ antiserum dilution in $3^{\text {rd }}$ immunization cycle (Table 3 ) which clearly indicated that the immune response was the highest in $3^{\text {rd }}$ immunization cycle. The immune response significantly increased from $1^{\text {st }}$ immunization cycle to $3^{\text {rd }}$ immunization cycle at $1 / 100$ serum dilution and decreased in $4^{\text {th }}$ collection (Figure 3). Stanker et al. [10], Meier and Bianca [22], Chen et al. [23], Thal et al. [24] and Bremus et al. [25] used ELISA to confirm the presence of antibodies against cefteram, cefalexin and ceftiofur, cephalexin, cefquinome and cephalosposin group respectively and all of them obtained positive antibody titres. The results clearly indicated that specific immune response was produced by cephalosporin group of antibiotics which was in accordance with our results.

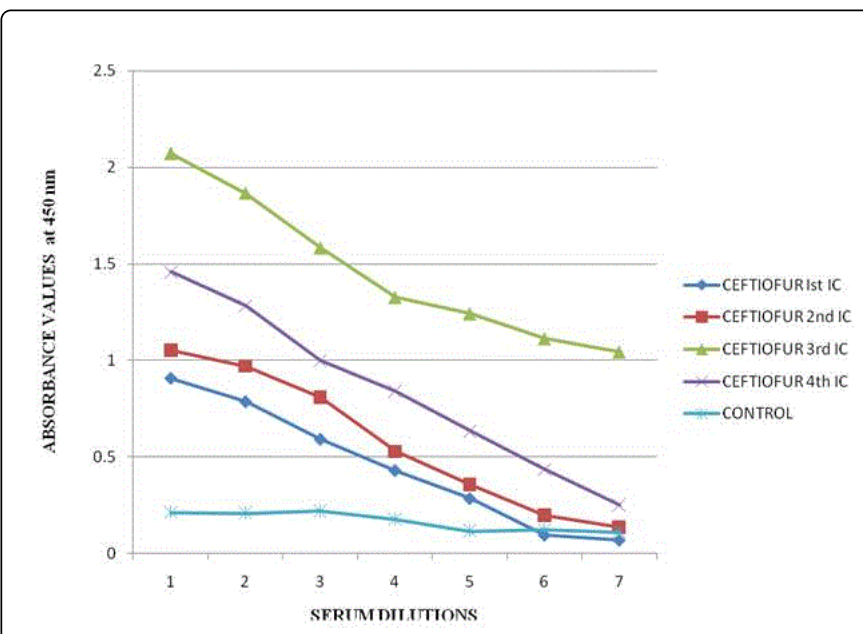

Figure 3: Calibration curve for Indirect ELISA of BSA-Ceftiofur antisera at various immunization cycles (IC) $(1,2,3,4,5,6,7$ represents serum dilutions of $1 / 100,1 / 200,1 / 400,1 / 800,1 / 1600$, $1 / 3200$ and $1 / 6400$ respectively).

\section{Comparative immunogenic potency of BSA-GEN and BSA- CEF antisera}

Highest immune response was seen in CEF antiserum followed by GEN evidenced by $\mathrm{OD}_{450}$ values of 2.072, 0.928 for CEF and GEN antisera respectively at $1 / 100$ serum dilution in 3rd immunization cycle (Figure 4). Least immune response in GEN was due to less efficient conjugation of GEN with BSA compared to CEF which might have resulted in low epitope density of hapten on the hapten-carrier protein conjugate. CEF has free carboxyl groups in its structure for conjugation with BSA whereas gentamycin has free amino groups. The most suitable coupling agents used to couple carboxyl group containing haptens to amines was carbodiimides and amino group containing haptens to amines, thiols, indoles and hydroxyls was glutaraldehyde [26]. But carbodiimides were also suggested to be suitable cross linkers for amino group containing haptens by Mingtao and Jiang [27].

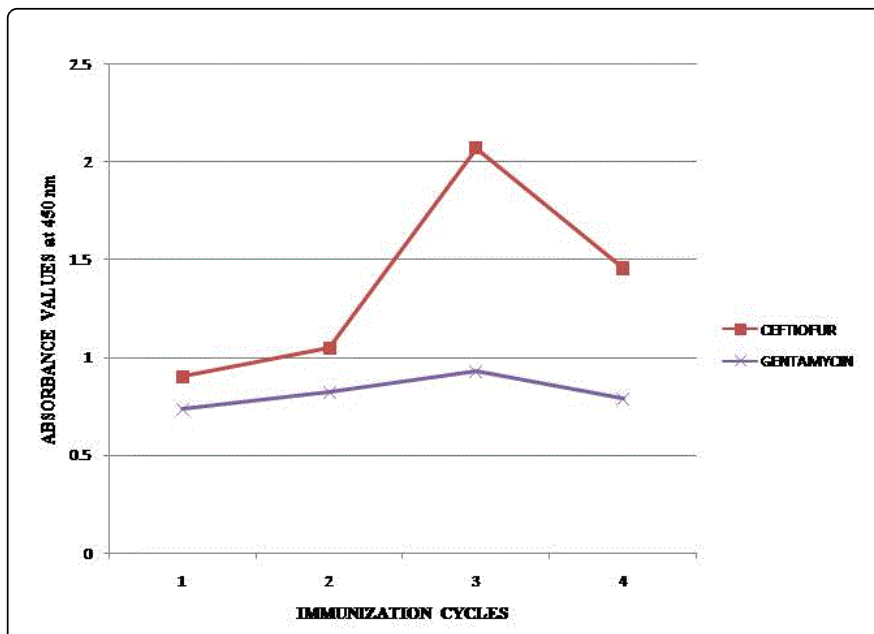

Figure 4: Comparative calibration curves for Indirect ELISA of BSA-antibiotic anisera at $1 / 100$ th serum dilution of various immunization cycles (IC) $(1,2,3,4$ represents 1 st, 2 nd, 3rd and 4th immunization cycles (IC) respectively at $1 / 100$ th serum dilution).

\section{Conclusion}

In the present study, the antibiotics (GEN and CEF) were successfully conjugated with BSA by carbodiimide reaction using EDC as a cross linker. These conjugated antibiotics were capable of producing pAbs which was confirmed by icELISA. But the immune response was poor in GEN antiserum when compared to the antisera of CEF. The pAbs produced against GEN and CEF can be used to develop immunoassay based diagnostic tests like lateral flow immunoassay and ELISA kits which can be used to detect antibiotic residues in the biological fluids like milk and urine samples.

\section{Acknowledgement}

The authors are gratefully acknowledging Sri Venkateshwara Veterinary University, Tirupathi for providing facilities for conducting this study.

\section{References}

1. Schwarz S, Kehrenberg C, Walsh TR (2001) Use of antimicrobial agents in veterinary medicine and food animal production. Int $\mathrm{J}$ Antimicrob Agents 17: 431-437.

2. NMPF (2011) Milk and dairy beef drug residue prevention, Producer manual of best management practices. National milk producers federation, pp: 1-60.

3. Barbosa TM, Levy SB (2000) The impact of antibiotic use on resistance development and persistence. Drug Resist Updat 3: 303-311.

4. Davis J (2007) Antibiotics: Food safety watch (Newsletter). Veterinary residues. 
Citation: Kumar SB, Ashok V, Kalyani P, Prasad PE, Krishnaiah N (2016) Production of Gentamycin and Ceftiofur Specific Polyclonal Antibodies by Conjugating them with Bovine Serum Albumin. J Veterinar Sci Techno 7: 314. doi:10.4172/2157-7579.1000314

Page 6 of 6

5. Liu C, Hong L, Limin C, Jie J (2005) Anti-ENR antibody production by using ENR-screened HSA as an immunogen. J Ocean U China 4: 262-266.

6. Cliquet P (2007) Production of penicillin-specific polyclonal antibodies for a group- specific screening ELISA. Food and agricultural immunology 18: 237-252.

7. Nijkamp FP, Parnham MJ (2011) Immune response in human pathology: Hypersensitivity and auto immunity. Principles of immune pharmacology 3rd revised and extended edition, Springer Basel AG, Switzerland, p: 141.

8. Suzanne NS, Lioyd EM (2003) Food analysis. (3rd Edn) Kluwer Academic/Plenum Publishers, New York, pp: 35-49.

9. Haasnoot W, Stouten P, Cazemier G, Lommen A, Nouws JF, et al. (1999) Immunochemical detection of aminoglycosides in milk and kidney. Analyst 124: 301-305.

10. Stanker LH (1998) A monoclonal antibody-based immunoassay for the detection of ceftiofur in milk. Food and Agricultural immunology 10: 121-131.

11. Christoph K (2002) Posttranslational modifications of proteins: tools for proteomics. Methods in molecular biology, pp: 194-247.

12. Bollag DM, Rozycki MD, Edelstein SJ (1996) Protein methods. (2nd Edn). General Biochemistry, Wiley-Liss publication, USA.

13. Dykman LA, Sumaroka MV, Staroverov SA, Zaitseva IS, Bogatyrev VA (2004) Immunogenic properties of colloidal gold. Biomedical and life sciences 31: 75-79.

14. Oruganti M, Gaidhani S (2011) Routine bleeding techniques in laboratory rodents. IJPR 2: 516-524.

15. Samsonova $\mathrm{ZhV}$ (2005) Enzyme-linked immunosorbent assay of ampicillin in milk. Applied Biochemistry and Microbiology 41: 589-595.

16. Fan GY (2012) Development of a class-specific polyclonal antibody based indirect competitive ELISA for detecting fluoroquinolone residues in milk. J Zhejiang Univ Sci B 13: 545-554.

17. Ramadass P (2008) Development of single serum dilution ELISA for detection of infectious bursal disease virus antibodies. Veterinarski arhiv 78: 23-30.
18. Jiang J (2011) Development of an immunoassay for determination of fluroquinolones pollutant in environmental water samples. IPCBEE 2: $1-4$.

19. Thrall MA (2004) Laboratory evaluation of plasma and serum proteins. In: Veterinary hematology and clinical chemistry. Lippincott Williams, Wilkins (Ed.), Philadelphia, USA, pp: 401-415.

20. Gobbo SP (2004) Standerdization of the immunoassays (ELISA) to detection of gentamycin in livestock using polyclonal antibody. Annual conference proceedings. Proceedings of the British Society of Animal Science. British Society of Animal Science, p: 107.

21. Jin Y, Jang JW, Lee MH, Han CH (2005) Development of competitive Enzyme-linked immunosorbent assay for the detection of gentamycin residues in the plasma of live animals. Asian Australas J Anim Sci 18: 1498-1504.

22. Meier M, Bianca F (2008) Development and application of enzyme immunological method for the detection of cefalexin, ceftiofur and desfuroylceftiofur in milk. scintifique, Giessen electronic library.

23. Chen L, Wang Z, Ferreri M, Su J, Han B (2009) Cephalexin residue detection in milk and beef by ELISA and colloidal gold based one-step strip assay. J Agric Food Chem 57: 4674-4679.

24. Thal J (2011) Development of an enzyme immunoassay for the antibiotic cefquinome and its application for residue determination in cow's milk after therapeutical mastitis treatment. Analytical and Bioanalytical Chemistry 399: 1051-1059.

25. Bremus A, Dietrich R, Dettmar L, Usleber E, Märtlbauer E (2012) A broadly applicable approach to prepare monoclonal anti-cephalosporin antibodies for immunochemical residue determination in milk. Anal Bioanal Chem 403: 503-515.

26. Harlow E, Lane D (1988) Antibodies: A Laboratory manual. (2nd edn). Cold Spring Harbor Laboratory Press, New York, USA.

27. Mingtao F, Jiang H (2011) Pesticides-Strategies for pesticide analysis. Pesticide Immunoassay. InTech Open Access, pp: 293-314. 